Koesoemo Ratih ${ }^{1}$, Harun Joko Prayitno ${ }^{2}$, Wibowo Heru Prasetyo ${ }^{3}$, Ika Irmawati ${ }^{4}$, Azka Dina Safitri ${ }^{5}$

1,23Fakultas Keguruan dan IImu Pendidikan Universitas Muhammadiyah Surakarta Email: koesoemo.ratih@ums.ac.id

\section{Penerapan Model Pembelajaran Blended di MII Subah pada Masa Pandemi Covid-19}

DOI: 10.18196/berdikari.v9i2.11951

\begin{abstract}
The covid-19 pandemic caused many problems on to the implementation of learning in schools. A blended learning strategy is by mixing two or more learning models. The learning model was implemented at Madrasah Ibtidaiyah Islamiyah (MII) Subah by combining face-to-face learning and online learning since it is more efficient and effective during the new normal during the Covid-19 pandemic. However, schools experience several obstacles, such as limited facilities and infrastructure to support the implementation of online learning and limited time for face-to-face learning at school. Therefore, schools need well-calculated time management to be utilized optimally. This service aimed to apply the blended learning model in increasing student interest and encouraging maximum learning outcomes. The service applied the advocacy method by providing direct assistance to students. The results of the advocacy indirectly proved that the application of blended learning strategies to help students in minimizing the obstacles of fully online learning. This service provided many benefits for students to appreciate time and opportunities for better learning. Keywords:learning strategies, blended learning, covid-19 pandemic, new normal, madrasah ibtidaiyah.
\end{abstract}

\begin{abstract}
ABSTRAK
Masa pandemi banyak menimbulkan persoalan dalam kaitannya dengan implementasi pembelajaran di sekolah. Strategi pembelajaran blended ataublended learning adalah pembelajaran yang mencampurkan dua atau lebih model pembelajaran. Model pembelajaran ini digunakan diMadrasah Ibtidaiyah Islamiyah (MII) Subah denganmenggabungkan pembelajaran tatap muka dengan pembelajaran online karena dianggap lebih efisien dan efektif pada masa new normal pandemi Covid-19. Namun, sekolah mengalami beberapa kendala, seperti keterbatasan sarana dan prasarana untuk menunjang pelaksanaan pembelajaran online dan keterbatasan waktu belajar tatap muka di sekolah. Oleh karena itu, sekolah membutuuhkan manajemen waktu yang baik agar model ini dapat dimanfaatkan dengan maksimal.Pengabdian ini ditujukan untuk menerapkan model pembelajaran blended dalam peningkatan minat siswa dan mendorong hasil belajar lebih maksimal. Metode pengabdian yang digunakan adalah metode advokasi, yaitu dengan menggunakan pendampingan langsung kepada peserta didik. Hasiladvokasi tersebut secara tidak langsung membuktikan bahwa penerapan strategi blended learning dapat membantu peserta didik dalam meminimalisasikendala pembelajaran full online. Pengabdian ini banyak memberi manfaat bagi peserta didik untuk lebih menghargai waktu dan kesempatan, sehingga dapat belajarlebih baik. Kata Kunci: blended learning, covid-19, new normal, sekolah dasar, strategi pembelajaran.
\end{abstract}




\section{PENDAHULUAN}

Masa normal baru atau dalam bahasa Inggris disebut dengan new normal adalah suatu tatanan hidup baru untuk menghadapi situasi hidup setelah lockdown di tengah masa pandemi Covid-19 yang belum berakhir (Habibi et al., 2020). Pada masa new normal masyarakat diberikan kesempatan untuk beraktivitas di luar rumah dengan menjaga jarak dan menaati protokol kesehatan. Tatanan hidup masyarakat mengalami perbedaan setelah pembatasan sosial berakhir.

New normal juga berdampak pada dunia pendidikan, yaitu kegiatan belajar mengajar di awal pandemi dilaksanakan full online kini menjadi campuran. Kondisi tersebut mengubah model pembelajaran yang biasa digunakan terutama dalam memilih pembelajaran diadakan luar jaringan (luring) atau dalam jaringan (daring). Pada konteks pandemi ini, sekolah perlu mempertimbangkan model pembelajaran dengan kelebihan dan kekurangan masing-masing.

Pembelajaran luring atau tatap muka di luar jaringan internet dinilai efektif dan membuat peserta didik antusias dalam belajar. Pemberian materi juga dapat secara menyeluruh. Inilah salah satu alasan sebagian besar peserta didik lebih senang dan mudah memahami penjelasan materi melalui pembelajaran luring. (Nengrum et. al., 2021). Pembelajaran luring masih bertahan sebagai model pembelajaran yang disukai peserta didik karena dinilai lebih sederhana dalam prosesnya. Media dan materi sudah disediakan oleh guru sehingga peserta didik tinggal mengikuti proses pembelajarannya, tidak perlu risau dengan permasalahan jaringan maupun komponen lainnya.

Solong (2021) berpendapat bahwa dalam pembelajaran online melalui video yang diperoleh dari internet atau video penjelasan dari guru yang dibagikan melalui grup WhatsApp dinilai mudah. Namun, bagi peserta didik yang memiliki keterbatasan sinyal dan kuota hal ini dinilai sulit. Peserta didik yang lebih suka belajar sambil melakukan aktivitas jika menonton video dalam durasi cukup panjang akan merasa bosan dan mengantuk.

Menteri Pendidikan RI membolehkan pemerintah daerah membuat kebijakan pembelajaran tatap muka bagi daerah bukan zona merah awal tahun 2021 (Widyawati, 2021). Kebijakan ini merupakan kabar baik bagi daerah zona hijau yang mengalami banyak kendala ketika pembelajaran online. Kendala tersebut berdampak pada tingkat pemahaman peserta didik terhadap materi pelajaran serta guru dalam memantau perkembangan peserta didik.

Blended learning atau pembelajaran campuran merupakan model pendidikan formal sehingga siswa dapat belajar online secara mandiri terhadap sarana dan prasarana yang 
digunakan (Staker \& Horn, 2012). Dengan kata lain, blended learning mencampurkan lebih dari satu model pembelajaran, seperti pembelajaran daring dan luring.

Model pembelajaran daring dinilai cocok diterapkan pada tingkat sekolah dasar sederajat dalam keadaan pandemi Covid-19 (Made et al., 2020). Hal ini karena peserta didik setingkat Madrasah Ibtidaiyah membutuhkan pembelajaran yang lebih konkret dan menyenangkan. Dengan kata lain, belajar sambil bermain bagi kelas pemula. Blended learning ini juga sangat sesuai diterapkan di jenjang Sekolah Dasar dalam konteks terbatasnya sarana prasarana dan diharapkannya guru dalam mengintegrasikan ICT dalam pembelajaran sesuai kurikulum 2013 (Widodo \& Nugroho, 2019).

Daerah-daerah yang berstatus zona hijau atau aman diperbolehkan melakukan pembelajaran tatap muka dengan menaati protokol kesehatan serta membagi jadwal dengan benar agar tidak terlalu banyak kerumunan. Menteri pendidikan menyampaikan bahwa setidaknya 50\% peserta didik yang hadir pada satu hari pembelajaran (Makarim, 2021). Kebijakan ini diberikan dengan berbagai pertimbangan, salah satunya kondisi tiap daerah yang berbeda-beda. Permasalahan-permasalahan yang muncul terkait pembelajaran penuh secara daring menjadi pertimbangan pemerintah untuk memperbolehkan melakukan pembelajaran tatap muka diawal tahun 2021. Pembelajaran online di masa pandemi dapat menekan tingkat penyebaran virus Covid-19. Kebijakan ini tentunya demi kebaikan masyarakat Indonesia. Pembelajaran dapat dilakukan di mana saja dan kapan saja dengan jaringan internet yang bagus. Referensi materi pelajaran pun dapat diperoleh dengan mudah melalui internet.

Dewasa ini pengetahuan dapat diperoleh dengan mudah melalui internet dan sangat mempermudah proses pembelajaran online. Meskipun demikian, permasalahan sarana pembelajaran online seperti terbatasnya kuota internet dan fasilitas HP memberikan pengaruh besar bagi proses pembelajaran. Kegiatan pembelajaran di masa new normal menjadikan sarana dan prasarana pembelajaran online menjadi sangat vital. Hal ini karena pembelajaran dapat berjalan apabila komponen tersebut dapat digunakan dengan baik. Tentunya dengan manfaat dan kendalanya masing-masing.

Berdasarkan kendala tersebut, Tim Kuliah Kerja Nyata Pendidikan (KKN Pendidikan) merumuskan beberapa rumusan masalah. Di antaranya, bagaimana pelaksanaan model pembelajaran blended di Madrasah Ibtidaiyah Islamiyah (MII) Subah dan bagaimana meningkatkan pemahaman peserta didik terkait model pembelajaran blended yang diterapkan. Bimbingan ini perlu diberikan kepada peserta didik agar lebih menghargai setiap waktu yang ada. Berdasarkan pemaparan di atas, tim pengabdian menerapkan blended learning di MII Subah. 


\section{METODE PELAKSANAAN}

Pengabdian ini menggunakan metode advokasi, yaitu pendampingan langsung kepada peserta didik MII Subah. Metode ini merupakan bentuk usaha yang dilakukan secara sistematis dan terorganisasi agar bisa mempengaruhi terjadinya kebijakan baru yang berpihak pada komunitas tertentu secara bertahap untuk maju (Adeliani et al., 2019).

Kegiatan pengabdian masyarakat pendidikan lapangan ini tidak memiliki model yang linier karena tim pelaksana berhadapan dengan berbagai situasi sosial yang sangat kompleks sehingga fleksibilitas mendapat penekanan (Ratih, Utami, et al., 2020). Adapun subjek pengabdian ini adalah peserta didik kelas 1 sampai 6 MII Subah. Untuk mempertajam analisis situasi, tim KKN Pendidikan ini menerapkan beberapa teknik pengumpulan data, yaitu observasi, wawancara, dan studi dokumentasi. Data yang diperoleh kemudian dianalisis kembali secara menyeluruh dan mengambil data-data yang penting karena data yang terkumpul kemungkinan bersumber dari penggunaan teknik pengumpulan data yang bervariasi yang belum tentu semuanya sesuai dan bisa digunakan (Ratih, Srijono, et al., 2020).

\section{HASIL DAN PEMBAHASAN}

Strategi pembelajaran yang digunakan dapat mempengaruhi mutu pembelajaran, baik di masa pandemi maupun tidak. Pembelajaran yang dilakukan secara penuh online dapat berjalan dengan baik di tertentu dan masyarakat tertentu. Penyebab munculnya masalah baru pada pembelajaran online adalah sarana dan prasarana yang kurang mendukung. Masalah tersebut di antaranya tidak dapat mengikuti pembelajaran karena HP dibawa orang tua bekerja atau kuota internet yang habis dan lain sebagainya.

Kendala lain yang sering dikeluhkan orang tua peserta didik adalah guru memberikan banyak tugas, tetapi di rumah anak lebih senang bermain. Orang tua merasa kewalahan, ditambah guru tidak begitu menguasai IT sehingga kurang maksimal dalam pembelajaran (Di et al., 2021). Ini berarti bahwa masih banyak tantangan yang dihadapi oleh sekolah dasar dalam menegelola kegiatan pembelajaran pada era komunikasi dan komputasi global ini (Prayitno, et al., 2020).

Kebijakan pemerintah untuk menerapkan pembelajaran tatap muka terbatas dengan mematuhi protokol kesehatan (prokes) dimanfaatkan dengan baik oleh kepala sekolah MII Subah. Sekolah menerapkan pendampingan belajar tatap muka selama 4 hari dalam satu minggu. Pendampingan belajar tatap muka dilakukan seperti biasa dengan durasi yang lebih singkat, yaitu 4 jam per harinya. Peserta didik juga diwajibkan menaati prokes seperti mencuci tangan sebelum dan sesudah melakukan kegiatan serta memakai masker. 
Jadwal setiap kelas ada yang berbeda sehingga meminimalisasi terjadinya kerumunan di lingkungan sekolah.

Dua hari sisanya peserta didik memperoleh materi pelajaran dan berdiskusi secara online melalui grup WhatsApp dengan bimbingan dan pengawasan orang tua dan guru. Materi yang dibagikan berupa file MS. Word, PDF, dan video pembelajaran. Ringkasan materi dibuat oleh guru, sedangkan video pembelajaran dikombinasikan antara video dari YouTube dan video yang diperagakan oleh guru. Ketika terdapat kendala dalam memahami materi, peserta didik dapat bertanya dan nantinya akan dijelaskan lebih detail oleh guru ketika tatap muka di sekolah.

Kemampuan guru dalam mengajarkan pengetahuan berpengaruh terhadap kualitas serta pencapaian peserta didik (Panambaian, 2020). Pembelajaran blended dapat berjalan dengan baik apabila terjadi kerjasama yang baik antara guru dan peserta didik. Tanggung jawab guru untuk menyalurkan pengetahuan dengan baik, memaksimalkan ketersediaan waktu yang terbatas dengan tetap mencontohkan taat protokol kesehatan, serta peserta didik yang paham bahwa pihak sekolah selalu memberikan solusi terbaik untuk peserta didiknya.

Secara tidak langsung, strategi blended learning dapat menjadi solusi peserta didik MII Subah yang terkendala ketika belajar online secara penuh. Selain itu, strategi ini dapat mengurangi kebosanan karena sudah lama tidak belajar bersama dengan teman-teman secara luring. Strategi ini juga meningkatkan semangat peserta didik untuk belajar di masa pandemi Covid-19. Indriani (2019) berpendapat bahwa ketika peserta didik sudah memiliki motivasi belajar maka segala sesuatu yang berhubungan dengan pembelajaran dapat diikutinya dengan antusias dan baik. Motivasi sangat krusial dalam aktivitas pembelajaran karena mampu mendorong semangat belajar. Motivasi merupakan syarat mutlak dalam belajar, yaitu seorang siswa yang belajar dan tanpa motivasi (atau kurang motivasi), pembelajar tidak akan berhasil dengan optimal (Syafii et. al., 2020).

Setelah dua minggu KKN Pendidikan berjalan, kami mengadakan kegiatan bersama kelas 5 a dan 5 b, yaitu belajar mengenai poster edukasi dilanjutkan dengan memberikan edukasi mengenai model blended learning. Dalam proses pembelajaran, peserta didik yang memiliki HP diperbolehkan menggunakan internet untuk memperoleh informasi. Pada hari-hari biasa, peserta didik tidak diperbolehkan membawa HP. Akan tetapi, pada program KKN Pendidikan yang berhubungan dengan alat elektronik dan internet pihak, sekolah memberikan izin kepada peserta didik.

Sebagian dari mereka tidak memiliki kuota. Dengan fasilitas Wi-Fi gratis dari tim KKN Pendidikan, dapat dilihat bahwa sebagian besar peserta didik sudah bisa 
memperoleh informasi secara mandiri melalui internet. Hal ini berdasarkan pengamatan, yaitu ketika peserta didik mendapat tugas untuk mencari informasi dari internet, sedikit dari mereka yang bertanya mengenai caranya. Di sisi lain, terdapat peserta didik yang tidak membawa HP. Beberapa di antara mereka tidak membawa HP karena belum difasilitasi HP pribadi oleh orang tua sehingga kegiatan belajar dan bimbingan menggunakan HP maupun laptop milik mahasiswa KKN Pendidikan.

Ketika masuk sesi edukasi model blended learning, peserta didik masih asing dengan istilah ini. Setelah dijelaskan, peserta didik paham bahwa model pembelajaran yang digunakan oleh sekolah adalah model blended learning. Dalam kegiatan diskusi bersama tim KKN Pendidikan, peserta didik menemukan banyak istilah baru mengenai model blended learning. Berdasarkan hasil analisis, peserta didik semakin menyadari pentingnya menghargai waktu pada saat belajar baik di sekolah maupun online. Hal ini dibuktikan dengan semua peserta didik lebih senang belajar tatap muka, tetapi tetap mematuhi peraturan sekolah dengan ikut serta belajar online dua hari dalam satu minggu.

Dalam konteks kemandirian belajar, penggunaan blended learning dapat mendorong peserta didik untuk dapat meningkatkan manajemen diri. Waseso dan Fuadi (2020) menyatakan bahwa peserta didik ditantang untuk dapat mengelola pengalaman belajar yang dikehendaki. Dengan sumber informasi yang beragam dan mudah diakses, guru memastikan bahwa peserta didik memiliki keterampilan untuk mengakses dan memilih informasi yang diperlukan. Guru dapat menjalankan peran sebagai fasilitator dengan memberikan motivasi sekaligus melakukan pengawasan atau controlling. Proses ini sesuai dengan konsep self-directed learning yang merupakan strategi untuk mewujudkan pembelajar sepanjang hayat (lifelong learner).

Pembelajaran tatap muka di MII Subah dinilai efektif karena interaksi secara langsung dapat meminimalisasi kesalahpahaman antara guru dan peserta didik. Pembelajaran lebih menyenangkan dengan menggunakan media pembelajaran yang menarik dan representatif. Berinteraksi langsung dengan teman-teman dapat membawa suasana hati peserta didik menjadi lebih baik.

Setelah 3 minggu program KKN berjalan, dilakukan analisis dengan memberikan kuesioner kepada kelas 5a dan 5b mengenai pelaksanaan pembelajaran blended di sekolah. Hasilnya sebagian besar peserta didik memilih pembelajaran tatap muka karena lebih mudah dalam memahami materi. Alasan lain peserta didik memilih pembelajaran tatap muka adalah minimnya kuota internet dan sinyal disekitar rumah. Dengan diterapkannya blended learning peserta didik jadi lebih bisa menghargai waktu pembelajaran tatap muka yang relatif singkat, yaitu 4 jam dalam satu harinya. 
Model pembelajaran blended ini diharapkan menjadi solusi bagi permasalahan baru yang muncul dalam dunia pendidikan pada masa pandemi Covid-19. Strategi blended learning menggabungkan pembelajaran daring dan tatap muka sehingga pembelajaran tatap muka dapat dijadikan sebagai solusi dalam memantapkan pemahaman materi ketika pembelajaran online belum dipahami dengan maksimal.

Integrasi pembelajaran daring dan luring membutuhkan manajemen pembelajaran yang melibatkan guru dan orang tua. Solong (2021) mengatakan bahwa guru tetap berperan paling besar dari tahapan persiapan, pelaksanaan, dan evaluasi pembelajaran. Orang tua dapat berperan dalam memberikan pendampingan dan pengawasan ketika anak belajar mandiri di rumah. Orang tua juga perlu terus menjalin komunikasi dengan guru terutama ketika peserta didik mengalami kendala dalam memahami materi dan mengerjakan tugas, termasuk mendapatkan masukan dari guru untuk mengurangi beban belajar dan kebosanan selama pembelajaran daring. Ketika pembelajaran dilaksanakan secara tatap muka di sekolah, guru dapat memberikan penguatan materi melalui pengayaan dan remedial.

Penggabungan antara pembelajaran online dan pembelajaran tatap muka mungkin sudah lebih awal diterapkan di sekolah dasar atau Madrasah Ibtidaiyah lainnya, khususnya sekolah dengan fasilitas komputer yang memadai dan masyarakat kota besar dengan fasilitas jaringan internet yang bagus. Akan tetapi, hal ini merupakan sesuatu yang baru bagi Madrasah Ibtidaiyah Islamiyah Subah. Salah satu faktornya adalah keterbatasan kuota internet dan fasilitas HP peserta didik. Maka dari itu, strategi blended ini sesuai dengan solusi yang dapat membantu mewujudkan harapan dan tujuan kepala sekolah dan guru.

Kepala sekolah memiliki harapan bahwa peserta didik lulusan MIISubah tidak menjadi lulusan Corona. Lulusan Corona yang dimaksud adalah tidak memiliki pemahaman pengetahuan yang baik seperti anggapan sebagian masyarakat karena pembelajaran dilakukan sakadarnya dan adanya keterbatasan keterampilan IT guru maupun fasilitas untuk mengakses internet. Harapan MII Subah yaitu mencetak lulusan yang dapat melanjutkan pendidikan selanjutnya dengan nilai yang bagus, berprestasi, berakhlak mulia, dan bisa belajar di sekolah yang diimpikan.

Perbandingan sebelum dilaksanakannya pembelajaran tatap muka empat kali dalam satu minggu serta dua hari pembelajaran online, dengan dua kali dalam satu minggu pembelajaran tatap muka, yaitu peserta didik jadi lebih memahami materi karena lebih banyak waktu diskusi dan penjelasan tatap muka. Jika dilihat dalam presentase, peserta didik yang lebih senang belajar tatap muka adalah 100\%. Survei kesiapan belajar online 
adalah 40\% banding 60\%. Peserta didik dan guru juga semakin menghargai waktu tatap muka yang ada dengan lebih maksimal untuk mencapai tujuan pembelajaran yang diharapkan. Selain itu, guru lebih mudah dalam memantau perkembangan belajar peserta didik. Hasil tersebut terhitung hingga 5 Maret 2021.

Hasil analisis terhadap efektivitas blended learning di atas didukung oleh beberapa temuan pada studi-studi terdahulu. (Ekantini, 2020) menemukan bahwa rata-rata hasil belajaran siswa menggunakan pembelajaran luring memang lebih baik dibandingkan dengan pembelajaran daring. Pembelajaran luring dianggap lebih nyaman bagi siswa untuk dapat merekonstruksi pemahaman materi dari kegiatan mengamati dan pengalaman belajar secara langsung. Meskipun terdapat studi yang membuktikan bahwa tidak terdapat perbedaan dari hasil pembelajaran full online dan blended learning (Maskar et. al., 2020), tetapi blended leaming dapat meningkatkan hasil belajar dibandingkan dengan hanya pembelajaran daring (Fap \& Hardini, 2021; Lestari \& Sufia, 2020).

\section{SIMPULAN}

Pengenalan strategi pembelajaran blended dan manfaatnya kepada peserta didik dapat membantu meningkatkan semangat belajar peserta didik secara tatap muka maupun online di masa pandemi Covid-19. Penerapan strategi pembelajaran blended di MII Subah merupakan keputusan yang tepat. Dengan mematuhi protokol kesehatan, pembelajaran tatap muka dapat dilaksanakan empat kali dalam satu minggu. Dua hari sisanya dilakukan secara online. Strategi blended learning ini dapat meminimalisasi kendala yang terjadi ketika pembelajaran dilakukan full online. Strategi ini dapat membantu mewujudkan harapan sekolah dalam meluluskan peserta didik yang berkompetensi, berprestasi, dan berakhlak mulia.

\section{DAFTAR PUSTAKA (REFERENCES)}

Adeliani, N., Andriyani, L., Diniati, S., Jayanti, A. S., Agustin, R. E., \& Aprilian, R. (2019). Advokasi Penanganan Pembuangan Sampah Liar. September.

Di, P. C.-, Negeri, S. D., \& Bendosari, S. (2021). Strategi Pembelajaran melalui Daring dan Luring Selama.2(1), 1-8.

Ekantini, A. (2020). Metode Pembelajaran Daring. Efektivitas Pembelajaran Daring pada Mata Pelajaran IPA di Masa Pandemi Covid-19: Studi Komparasi Pembelajaran Luring dan Daring pada Mata Pelajaran IPA SMP, 5(2), 187-194.
Fap, A. M., \& Hardini, A. T. A. (2021). Blended learning untuk meningkatkan hasil belajar dan motivasi belajar di masa pandeml Covid-19. Jurnal Inovasi Teknologi Pendidikan, 8(1). Habibi, A., Normal, N., \& Baru, N. (2020). Normal Baru Pasca Covid-19. 4, 197-204.

Indriani, D. (2019). Pengaruh Model Blended Learning Terhadap Motivasi dan Prestasi Belajar.3, 851-854.

Lestari, U. N., \& Sufia, R. (2020). Implementasi Blended Learning Selama Masa Pandemi Covid-19 untuk Menumbuhkan Kemandirin 
Siswa pada Mata Pelajaran Matematika di SD YP Nasional .... JIEES: Journal of Islamic Education at ..., 12), 103-110.

Made, D., Putra, D., Guru, P., Dasar, S., Dwijendra, U., \& Learning, B. (2020). Integrasi Pendidikan Karakter Dalam Penerapan Blended Learning Di Sekolah Dasar. 3(3), 472-484.

Maskar, S., Dewi, P. S., \& Puspaningtyas, N. D. (2020). Online Learning \& Blended Learning: Perbandingan Hasil Belajar Metode Daring Penuh dan Terpadu. Prisma, 9(2), 154. https:// doi.org/10.35194/jp.v9i2.1070

Nengrum, T. A., Petta, N., Nur, M., Nengrum, T. A., Petta, N., \& Nur, M. (2021). Kelebihan dan Kekurangan Pembelajaran Luring dan Daring dalam Pencapaian Kompetensi Dasar Kurikulum Bahasa Arab di Madrasah Ibtidaiyah 2 Kabupaten Gorontalo Strengths and Weaknesses of Offline and Online Learning In Achieving Basic Competencies of The Ara. 301), 1-12.

Panambaian, T. (2020). Penerapan Program Pengajaran dengan Model Blended Learning pada Sekolah.22(1), 52-68.

Prayitno, H. J., Wulandari, M. D., Widyasari, C., Nursalam, N., Malaya, K. A., Bachtiar, F. Y., Hermawan, H., Wulandari, D. T., \& Aditama, M. G. (2020). Pemberdayaan Guru dalam Peningkatan Layanan Bimbingan Konseling di SD/MI Muhammadiyah Se-Surakata pada Era Komunikasi Global. Buletin KKN Pendidikan, 2(2), 56-62. https://doi.org/10.23917/ bkkndik.v2i2.11853

Ratih, K., Srijono, D., Laksono, G. Y., Dewi, A. K., Jusup, B., Fitriyani, F., Hasanah, A. U., Farida, K., Pramesti, M. E., Styaningsih, N. P., Darojati, S. M., \& Mirwanti, W. (2020). Penguatan Nilai dan Karakter Nasionalisme melalui Lagu Wajib Nasional di MI Muhammadiyah Tanjungsari, Boyolali. Buletin KKN Pendidikan, 2(2), 75-78. https://doi.org/10.23917/bkkndik.v2i2.10793

Ratih, K., Utami, R. D., Fuadi, D., Mulyasih, S., \& Febriani, D. (2020). Penguatan Pendidikan Etika dan Karakter Peduli Lingkungan Sosial Budaya di SMP Muhammadiyah 10 Matesih , Karanganyar. 2(1), 44-49. https://doi.org/ 10.23917/bkkndik.v2i1.10770

Solong, N. P. (2021). Manajemen Pembelajaran Luring dan Daring dalam Pencapaian Kompetensi. Tadbir: Jurnal Manajemen
Pendidikan Islam, 9, 19-32.

Staker, B. H., \& Horn, M. B. (2012). Classifying K - 12 Blended Learning. May.

Syafii, M. L., Kusnawan, W., \& Syukroni, A. (2020). Penumbuhkembangan Motivasi Guru Madrasah Tsanawiyah Mambaul Ulum Perdana dalam Peningkatan Kualitas Pendidikan. BERDIKAR// : Jurnal Inovasi Dan Penerapan Ipteks, 8(2), 92103. https://doi.org/10.18196/bdr.8281

Waseso, H. P., \& Fuadi, S. I. (2020). Implementasi Pembelajaran Berbasis Blended Learning Menggunakan Media Whatsapp untuk Meningkatkan Self Directed Learning Mahasiswa. Jurnal Penelitian Dan Pengabdian Kepada Masyarakat UNSIQ, 72), 202-212. https://doi.org/10.32699/ppkm.v7i2.1275

Widodo, N., \& Nugroho, S. (2019). Peningkatan Pemahaman Kurikulum 2013 bagi Guru Sekolah Dasar. BERDIKARI/ : Jurnal Inovasi Dan Penerapan Ipteks, 72), 171-186. https://doi.org/ 10.18196/bdr.7270

Widyawati; D. (2021). b Sekolah Tatap Muka Dimulai Januari 2021, Peran Bidang Kesehatan Ditingkatkan - Sehat Negeriku. Redaksi Sehat Negeriku.

Wisaksono, A., Masruchin, M., Purwanti, Y., \& Nurbaya, S. R. (2020). Pemanfaatan Aplikasi Evaluasi Belajar Berbasis Web Era Covid - 19. BERDIKARI/ : Jurnal Inovasi Dan Penerapan Ipteks, 8(2), 104-114. https://doi.org/10.18196/ bdr.8282

Adeliani, N., Andriyani, L., Diniati, S., Jayanti, A. S., Agustin, R. E., \& Aprilian, R. (2019). Advokasi Penanganan Pembuangan Sampah Liar. September.

Di, P. C.-, Negeri, S. D., \& Bendosari, S. (2021). Strategi Pembelajaran Melalui Daring dan Luring Selama.2(1), 1-8.

Ekantini, A. (2020). Metode Pembelajaran Daring. Efektivitas Pembelajaran Daring pada Mata Pelajaran IPA di Masa Pandemi Covid-19: Studi Komparasi Pembelajaran Luring dan Daring pada Mata Pelajaran IPA SMP, 5(2), 187-194.

Fap, A. M., \& Hardini, A. T. A. (2021). Blended learning untuk meningkatkan hasil belajar dan motivasi belajar di masa pandeml Covid-19. Jurnal Inovasi Teknologi Pendidikan, 8(1). Habibi, A., Normal, N., \& Baru, N. (2020). Normal Baru pasca Covid-19. 4, 197-204.

Indriani, D. (2019). Pengaruh Model Blended 
Learning terhadap Motivasi dan Prestasi Belajar.3, 851-854.

Lestari, U. N., \& Sufia, R. (2020). Implementasi Blended Learning Selama Masa Pandemi Covid-19 untuk Menumbuhkan Kemandirin Siswa pada Mata Pelajaran Matematika di SD YP Nasional .... JIEES: Journal of Islamic Education at ..., 12), 103-110.

Made, D., Putra, D., Guru, P., Dasar, S., Dwijendra, U., \& Learning, B. (2020). Integrasi Pendidikan Karakter Dalam Penerapan Blended Learning Di Sekolah Dasar. 3(3), 472-484.

Maskar, S., Dewi, P. S., \& Puspaningtyas, N. D. (2020). Online Learning \& Blended Learning: Perbandingan Hasil Belajar Metode Daring Penuh dan Terpadu. Prisma, 9(2), 154. https:// doi.org/10.35194/jp.v9i2.1070

Nengrum, T. A., Petta, N., Nur, M., Nengrum, T. A., Petta, N., \& Nur, M. (2021). Kelebihan dan Kekurangan Pembelajaran Luring dan Daring dalam Pencapaian Kompetensi Dasar Kurikulum Bahasa Arab di Madrasah Ibtidaiyah 2 Kabupaten Gorontalo Strengths and Weaknesses of Offline and Online Learning In Achieving Basic Competencies of The Ara. 301), $1-12$.

Panambaian, T. (2020). PENERAPAN Program Pengajaran dengan Model Blended Learning pada Sekolah.22(1), 52-68.

Prayitno, H. J., Wulandari, M. D., Widyasari, C., Nursalam, N., Malaya, K. A., Bachtiar, F. Y., Hermawan, H., Wulandari, D. T., \& Aditama, M. G. (2020). Pemberdayaan Guru dalam Peningkatan Layanan Bimbingan Konseling di SD/MI Muhammadiyah Se-Surakata pada Era Komunikasi Global. Buletin KKN Pendidikan, 2(2), 56-62. https://doi.org/10.23917/ bkkndik.v2i2.11853

Ratih, K., Srijono, D., Laksono, G. Y., Dewi, A. K., Jusup, B., Fitriyani, F., Hasanah, A. U., Farida, K., Pramesti, M. E., Styaningsih, N. P., Darojati, S. M., \& Mirwanti, W. (2020). Penguatan Nilai dan Karakter Nasionalisme melalui Lagu Wajib Nasional di MI Muhammadiyah Tanjungsari, Boyolali. Buletin KKN Pendidikan, 2(2), 75-78. https://doi.org/10.23917/bkkndik.v2i2.10793

Ratih, K., Utami, R. D., Fuadi, D., Mulyasih, S., \& Febriani, D. (2020). Penguatan Pendidikan Etika dan Karakter Peduli Lingkungan Sosial Budaya di SMP Muhammadiyah 10 Matesih,
Karanganyar. 2(1), 44-49. https://doi.org/ 10.23917/bkkndik.v2i1.10770

Solong, N. P. (2021). Manajemen Pembelajaran Luring dan Daring dalam Pencapaian Kompetensi. Tadbir: Jurnal Manajemen Pendidikan Islam, 9, 19-32.

Staker, B. H., \& Horn, M. B. (2012). Classifying K - 12 Blended Learning. May.

Syafii, M. L., Kusnawan, W., \& Syukroni, A. (2020). Penumbuhkembangan Motivasi Guru Madrasah Tsanawiyah Mambaul Ulum Perdana dalam Peningkatan Kualitas Pendidikan. BERDIKARI/ Jurnal Inovasi dan Penerapan Ipteks, 8(2), 92103. https://doi.org/10.18196/bdr.8281

Waseso, H. P., \& Fuadi, S. I. (2020). Implementasi Pembelajaran Berbasis Blended Learning Menggunakan Media Whatsapp untuk Meningkatkan Self Directed Learning Mahasiswa. Jurnal Penelitian dan Pengabdian Kepada Masyarakat UNSIQ, 72), 202-212. https://doi.org/10.32699/ppkm.v7i2.1275

Widodo, N., \& Nugroho, S. (2019). Peningkatan Pemahaman Kurikulum 2013 bagi Guru Sekolah Dasar. BERDIKARI/ : Jurnal Inovasi dan Penerapan Ipteks, 72 ), 171-186. https://doi.org/ 10.18196/bdr.7270

Widyawati;, D. (2021). b Sekolah Tatap Muka Dimulai Januari 2021, Peran Bidang Kesehatan Ditingkatkan - Sehat Negeriku. Redaksi Sehat Negeriku.

Wisaksono, A., Masruchin, M., Purwanti, Y., \& Nurbaya, S. R. (2020). Pemanfaatan Aplikasi Evaluasi Belajar Berbasis Web Era Covid - 19. BERDIKARII : Jurnal Inovasi Dan Penerapan Ipteks, 8(2), 104-114. https://doi.org/10.18196/ bdr.8282 